\title{
Response to recurrent selection under small effective population size
}

\author{
Cláudio Lopes de Souza Jr., Isaias Olívio Geraldi and Roland Vencovsky
}

\begin{abstract}
A formula was derived for the prediction of the response to recurrent selection when the effective population size $\left(\mathrm{N}_{\mathrm{e}}\right)$ is small. Usually, responses to selection have been estimated by $\mathrm{Rs}=\mathrm{ic} \sigma_{{ }_{\mathrm{A}}} / \sigma_{\mathrm{Ph}}$, where $\mathrm{i}, \mathrm{c}, \sigma_{\mathrm{A}}^{2}$, and $\sigma_{\mathrm{Ph}}$ stand for standardized selection differential, parental control, additive variance, and phenotypic standard deviation, respectively. This expression, however, was derived under the assumption of infinite population size. By introducing the effects of finite population size, the expression derived was Rs $=\left[\mathrm{ic}\left(\sigma_{\mathrm{A}}^{2}+\Delta \mathrm{FD}_{1}\right) / \sigma_{\mathrm{Ph}}\right]-\Delta \mathrm{FID}$, where $\Delta F$, ID and $\mathrm{D}_{1}$ are the changes in the inbreeding coefficient, the inbreeding depression, and the covariance of additive and homozygous dominance effects, respectively. Thus, the predicted responses to selection based on these expressions will be smaller than those based on the standard procedures for traits with a high level of dominance such as yield. Responses to five cycles of half-sib selection were predicted for maize by both expressions, considering that 100 progenies were evaluated and $10 \mathrm{~S}_{1}$ progenies were recombined, which corresponds to $\mathrm{N}_{\mathrm{e}}=10$ for each cycle. The accumulated response to selection estimated with the new expression was about 47 and $28 \%$ smaller than that based on the standard expression for yield and plant height, respectively. Thus, the expression usually used overestimates the responses to selection, which is in agreement with reported results, because it does not take into account the effective population size that is generally small in recurrent selection programs.
\end{abstract}

\section{INTRODUCTION}

The improvement of populations through recurrent selection is a common procedure in breeding programs designed to develop hybrids from inbred lines in maize and other allogamous species. Several recurrent selection methods have been reported (Hallauer et al., 1988), and formulas for the expected response to selection for each method have been derived. These expressions are linear functions of the intensity of selection and of the additive genetic variance, and are inverse functions of the phenotypic variance (Empig et al., 1972; Cockerham and Matzinger, 1985).

Genetic drift is expected to occur in recurrent selection irrespective of the method, because of the small number of selected progenies recombined to give rise to the improved populations. Furthermore, to increase the genetic gain and to lower the genetic load of the populations, inbred progenies have been used for recombination. These factors lead to a decrease in the effective size of the population under selection in which genetic drift is likely to take place, as has been reported for maize populations (Smith, 1979a,b, 1983; Helms et al., 1989; Eyherabide and Hallauer, 1991; Keeratinijakal and Lamkey, 1993). Expected and observed responses to intrapopulation selection usually show large discrepancies (Burton et al., 1971; Penny and Eberhart, 1971; Crossa and Gardner, 1989; Arriel et al., 1993). A possible reason for these discrepancies may be that the expressions of the expected responses to selection have been derived for a random mating population under the assumption of infinite population size (Kempthorne, 1957; Falconer and Mackay, 1996). The objective of this study was to derive a general expression for the expected response to intrapopulation selection by taking into account the effects of finite population size and present experimental results for a maize population.

\section{MATERIAL AND METHODS}

\section{Genetic model}

Consider a random mating population in both HardyWeinberg and linkage equilibrium under intrapopulation recurrent selection. Let $\mathrm{p}_{0}$ and $\mathrm{q}_{0}$ be the frequencies of the favorable (B) and unfavorable (b) alleles, and a and $\mathrm{d}$ be half the difference of the homozygous effects and the dominance effects, respectively (Falconer and Mackay, 1996). After one cycle of recurrent selection the frequencies of $\mathrm{B}$ and $\mathrm{b}$ alleles will be $\mathrm{p}_{1}$ and $\mathrm{q}_{1}$, respectively. The changes in these frequencies are functions of both selection $(\Delta \mathrm{p})$ and drift $(\delta \mathrm{p})$. Then, $\varepsilon\left(\mathrm{p}_{1}\right)=\varepsilon\left(\mathrm{p}_{0}+\Delta \mathrm{p}+\delta \mathrm{p}\right)$, and $\varepsilon\left(\mathrm{q}_{1}\right)=$ $\varepsilon\left(\mathrm{q}_{0}-\Delta \mathrm{p}-\delta \mathrm{p}\right)$, where $\varepsilon(\Delta \mathrm{p})=\mathrm{icp}_{0} \mathrm{q}_{0} \alpha / \sigma_{\mathrm{Ph}}$ (Empig et al., $1972)$, and $\varepsilon(\delta \mathrm{p})=\varepsilon\left(\mathrm{p}_{0} \delta \mathrm{p}\right)=\varepsilon\left(\mathrm{q}_{0} \delta \mathrm{p}\right)=\varepsilon(\Delta \mathrm{p} \delta \mathrm{p})=0$, and $\varepsilon(\delta \mathrm{p})^{2}=\mathrm{p}_{0} \mathrm{q}_{\mathrm{o}} / 2 \mathrm{~N}_{\mathrm{e}}$ (Falconer and Mackay, 1996). In these expressions $\mathrm{i}$ is the standardized selection differential, $\mathrm{c}$ is the parental control, $\sigma_{\mathrm{Ph}}$ is the phenotypic standard deviation, $\mathrm{N}_{\mathrm{e}}$ is the effective size of the population, $\alpha=\mathrm{a}+$ $\left(\mathrm{q}_{0}-\mathrm{p}_{0}\right) \mathrm{d}$ is the average effect of gene substitution and $\varepsilon$ denotes expectation. We also assumed that changes in gene frequencies through recurrent selection are small, so one could assume that $\varepsilon(\Delta p)^{2} \cong 0$, and this term will therefore be neglected in the following derivations.

Following the genetic model, the mean of the origi- 
nal (unselected) population for one locus is $\mathrm{u}_{0}=\mathrm{u}+\left(\mathrm{p}_{0}\right.$ $\left.q_{0}\right) a+2 p_{0} q_{0} d$ and the mean of the population after one cycle of selection is $u_{1}=u+\left(p_{1}-q_{1}\right) a+2 p_{1} q_{1} d$. Now, substituting $\mathrm{p}_{1}$ and $\mathrm{q}_{1}$ in $\mathrm{u}_{1}$ by their expectations and after algebraic manipulations we will have $\mathrm{u}_{1}$ as a function of the original mean, the changes due to selection and drift. Then, the expected response to selection was derived from the contrast $\mathrm{Rs}=\mathrm{u}_{1}-\mathrm{u}_{0}$.

Inbreeding depression (ID) is usually estimated by the expression: ID $=2\left(u_{\mathrm{S} 0}-u_{\mathrm{S} 1}\right)$, where $\mathrm{u}_{\mathrm{S} 0}$ is the mean of the original population $\left(\mathrm{u}_{0}\right)$ and $\mathrm{u}_{\mathrm{S} 1}$ is the mean of this population after one generation of selfing, i.e., $u_{s 1}=u+\left(p_{0}-q_{0}\right) a$ $+\mathrm{p}_{0} \mathrm{q}_{0} \mathrm{~d}$. Then, inbreeding depression is ID $=2 \mathrm{p}_{0} \mathrm{q}_{0} \mathrm{~d}$. The inbreeding coefficient $\left(F_{t}\right)$ as a function of the effective population size in the $t^{\text {th }}$ generation is $F_{t}=\left(1 / 2 N_{e}\right)+[1-$ $\left.\left(1 / 2 \mathrm{~N}_{\mathrm{e}}\right)\right] \mathrm{F}_{\mathrm{t}-1}$, where $\mathrm{F}_{\mathrm{t}}$ and $\mathrm{F}_{\mathrm{t}-1}$ are the inbreeding coefficients in the $\mathrm{t}^{\text {th }}$ and $(\mathrm{t}-1)^{\mathrm{th}}$ generations, respectively. Then, the inbreeding depression due to the small population size is estimable by $\Delta \mathrm{FID}$ for each cycle of selection, where $\Delta \mathrm{F}$ is the change in the inbreeding coefficient (Falconer and Mackay, 1996).

\section{Experimental procedures}

Experimental data from ESALQ-PB1, an open-pollinated maize population, were used for illustration. One hundred pairs of $S_{1}$ and half-sib progenies were obtained in two-ear plants in a lower plant density field (25,000 plants/ ha) by selfing the lower ears and crossing the upper ears with a pollen mixture from 50 random plants. These pairs of progenies were evaluated in a randomized complete block design, with the half-sib and $\mathrm{S}_{1}$ progenies in a splitblock arrangement to avoid competition due to inbreeding depression. Each sub-plot was one row $4.0 \mathrm{~m}$ long with 1.0 $\mathrm{m}$ between rows, with 20 plants per sub-plot after thinning (50,000 plants/ha). The experiments were carried out at two locations in Piracicaba (SP) and one location in Uberlândia (MG), with three replications per location. Data on yield as the mean of unhusked ear weight, and on plant height as the mean of five competitive plants per sub-plot were recorded.

Analysis of variance was performed according to the experimental design. Subsequently, analyses of variance were computed for each progeny type for each environment, and then combined across environments. Inbreeding depression was estimated as ID $=2\left(\mathrm{~S}_{0}-\mathrm{S}_{1}\right)$ and ID $\%$ as $\left(\mathrm{ID} / \mathrm{S}_{0}\right) 100$, which corresponds to the expected total inbreeding depression, i.e., ID $=S_{0}-S_{\infty}$. In these expressions $S_{0}$ and $S_{1}$ refer to the general means of half-sibs and $S_{1}$ progenies, respectively (Table I). From the half-sib analysis, estimates of genetic and phenotypic parameters were obtained as follows: additive variance: $\sigma_{\mathrm{A}}^{2}=4\left(\mathrm{M}_{\mathrm{p}}-\mathrm{M}_{\mathrm{e}}\right) / \mathrm{RL}$; phenotypic variance among progeny means: $\sigma_{\mathrm{Ph}}^{2}=\mathrm{M}_{\mathrm{p}} / \mathrm{RL}$; and heritability $\left(\mathrm{h}_{\%}^{2}\right)=\left(\sigma_{\mathrm{A}}^{2} / 4 \sigma_{\mathrm{Ph}}^{2}\right) 100$, where $\mathrm{M}_{\mathrm{p}}$ and $\mathrm{M}_{\mathrm{e}}$ stand for progeny and error mean squares, and $\mathrm{R}$ and $\mathrm{L}$ are the number of replications and of locations, respectively.
The covariance of additive and homozygous dominance effects was estimated as $D_{1}=4\left[\operatorname{Cov}_{\mathrm{G}}\left(\mathrm{HS}, \mathrm{S}_{1}\right)-(1 / 2) \sigma_{\mathrm{A}}^{2}\right]$, where $\operatorname{Cov}_{\mathrm{G}}\left(\mathrm{HS}, \mathrm{S}_{1}\right)$ is the genetic covariance of half-sib and $\mathrm{S}_{1}$ progenies (Table II). For estimation of the expected response to selection, an intrapopulation half-sib selection was considered, where half-sib progenies and $S_{1}$ progenies are the selection and recombination units, respectively. Since the effective size of an $S_{1}$ progeny is 1 , the different effective population sizes considered in this paper refer to the number of recombined $S_{1}$ progenies.

\section{RESULTS AND DISCUSSION}

\section{Theoretical response to selection}

The expected mean value of a population following one cycle of selection is:

$$
\mathrm{u}_{1}=\mathrm{u}+\left(\mathrm{p}_{1}-\mathrm{q}_{1}\right) \mathrm{a}+2 \mathrm{p}_{1} \mathrm{q}_{1} \mathrm{~d},
$$

and substituting $\mathrm{p}_{1}$ and $\mathrm{q}_{1}$ by their expectations, we have:

$$
\begin{aligned}
\mathrm{u}_{1}= & \mathrm{u}+\left[\left(\mathrm{p}_{0}+\Delta \mathrm{p}+\delta \mathrm{p}\right)-\left(\mathrm{q}_{0}-\Delta \mathrm{p}-\delta \mathrm{p}\right)\right] \mathrm{a}+ \\
& +2\left(\mathrm{p}_{0}+\Delta \mathrm{p}+\delta \mathrm{p}\right)\left(\mathrm{q}_{0}-\Delta \mathrm{p}-\delta \mathrm{p}\right) \mathrm{d},
\end{aligned}
$$

and after algebraic manipulations, the expected mean of a population after one cycle of selection can be expressed as:

$$
\mathrm{u}_{1}=\mathrm{u}_{0}+2 \Delta \mathrm{p} \alpha-2(\delta \mathrm{p})^{2} \mathrm{~d}
$$

For a random sample from a base population, $\varepsilon(\delta p)^{2}$ $=\mathrm{p}_{0} \mathrm{q}_{0} / 2 \mathrm{~N}_{\mathrm{e}}($ Falconer and Mackay, 1996). However, to ac-

Table I - Mean values of grain yield ( $\mathrm{Y}$ ) and plant height $(\mathrm{PH})$ for ESALQ-PB1 maize population in the $S_{0}$ and $S_{1}$ generations, inbreeding depression (ID), and coefficient of experimental variation (CV\%).

\begin{tabular}{lcc|}
\hline Generation & $\mathrm{Y}$ (g/plant) & PH (cm/plant) \\
\hline $\mathrm{S}_{0}$ & $201.88 \pm 8.42$ & $213.31 \pm 5.54$ \\
$\mathrm{~S}_{1}$ & $118.91 \pm 9.37$ & $156.16 \pm 6.82$ \\
$\mathrm{ID}$ & $165.94 \pm 15.2$ & $114.30 \pm 10.4$ \\
$\mathrm{ID} \%$ & 82.2 & 53.6 \\
\hline $\mathrm{CV} \%\left(\mathrm{~S}_{0}\right)$ & 10.5 & 4.6 \\
$\mathrm{CV} \%\left(\mathrm{~S}_{1}\right)$ & 16.9 & 6.3 \\
\hline
\end{tabular}

Table II - Estimates of additive variance $\left(\sigma^{2}\right)$, phenotypic variance $\left(\sigma_{\mathrm{Ph}}^{2}\right), \mathrm{D}_{1}$, and heritability $\left(\mathrm{h}^{2}{ }_{\%}\right)$ from maize half-sib progenies, for yield $(\mathrm{Y})$ and plant height $(\mathrm{PH})$.

\begin{tabular}{|lrr|}
\hline Parameters & Y(g/plant $)$ & PH (cm/plant $)$ \\
\hline$\hat{\sigma}^{2}{ }_{\mathrm{A}}$ & $197.41 \pm 67.91$ & $184.39 \pm 42.48$ \\
$\hat{\sigma}^{2}$ & $111.63 \pm 15.79$ & $70.88 \pm 10.02$ \\
$\hat{\mathrm{D}}_{1}$ & $-50.32 \pm 19.39$ & $-34.72 \pm 11.30$ \\
$\hat{\mathrm{h}}_{\%}{ }_{\%}$ & $44.21 \pm 15.21$ & $65.04 \pm 14.98$ \\
\hline
\end{tabular}


commodate the situation in which changes in gene frequency occur both due to selection and drift, the set of selected genotypes was considered as the reference population for measuring the effect of sampling on allelic frequencies. Taking $\mathrm{p}_{0}=\mathrm{p}_{0}+\Delta \mathrm{p}$ as the gene frequency in this set then $\varepsilon\left(\delta \mathrm{p}^{\prime}\right)^{2}=\mathrm{p}^{\prime}{ }_{0} \mathrm{q}^{\prime}{ }_{0} / 2 \mathrm{~N}_{\mathrm{e}}$. Then, for the selected sample we have:

$$
\begin{aligned}
& \varepsilon\left(\delta \mathrm{p}^{\prime}\right)^{2}=\mathrm{p}^{\prime}{ }_{0} \mathrm{q}^{\prime}{ }_{0} / 2 \mathrm{~N}_{\mathrm{e}}=\left(\mathrm{p}_{0}+\Delta \mathrm{p}\right)\left(\mathrm{q}_{0}-\Delta \mathrm{p}\right) / 2 \mathrm{~N}_{\mathrm{e}} \text {, and } \\
& \varepsilon\left(\delta \mathrm{p}^{\prime}\right)^{2}=\left[\mathrm{p}_{0} \mathrm{q}_{0}+\Delta \mathrm{p}\left(\mathrm{q}_{0}-\mathrm{p}_{0}\right)\right] / 2 \mathrm{~N}_{\mathrm{e}} .
\end{aligned}
$$

Now, including $\varepsilon(\Delta p)$ in this expression leads to:

$$
\varepsilon\left(\delta p^{\prime}\right)^{2}=\left[\left(\mathrm{p}_{0} \mathrm{q}_{0} / 2 \mathrm{~N}_{\mathrm{e}}\right)+\mathrm{icp_{0 }} \mathrm{q}_{0}\left(\mathrm{q}_{0}-\mathrm{p}_{0}\right) \alpha / 2 \mathrm{~N}_{\mathrm{e}} \sigma_{\mathrm{Ph}}\right] .
$$

Then, substituting $\varepsilon(\Delta p)$ and $\varepsilon\left(\delta p^{\prime}\right)^{2}$ in $u_{1}$ we have:

$$
\begin{aligned}
\mathrm{u}_{1}= & \mathrm{u}_{0}+\left(\mathrm{ic} 2 \mathrm{p}_{0} \mathrm{q}_{0} \alpha^{2} / \sigma_{\mathrm{Ph}}\right)-\left[2 \mathrm{p}_{0} \mathrm{q}_{0} \mathrm{~d} / 2 \mathrm{~N}_{\mathrm{e}}+\right. \\
& \left.+i \mathrm{ic} 2 \mathrm{p}_{0} \mathrm{q}_{0}\left(\mathrm{q}_{0}-\mathrm{p}_{0}\right) \alpha \mathrm{d} / 2 \mathrm{~N}_{\mathrm{e}} \sigma_{\mathrm{Ph}}\right],
\end{aligned}
$$

with $\sigma_{\mathrm{A}}^{2}=2 \mathrm{p}_{0} \mathrm{q}_{0} \alpha^{2}, \mathrm{D}_{1}=-2 \mathrm{p}_{0} \mathrm{q}_{0}\left(\mathrm{q}_{0}-\mathrm{p}_{0}\right) \alpha \mathrm{d}$ and ID $=2 \mathrm{p}_{0} \mathrm{q}_{0} \mathrm{~d}$ as the additive variance, the covariance of additive and homozygous dominance effects, and the inbreeding depression, respectively, we have:

$$
\mathrm{u}_{1}=\mathrm{u}_{0}+\left[\mathrm{ic}\left(\sigma_{\mathrm{A}}^{2}+\Delta \mathrm{FD}_{1}\right) / \sigma_{\mathrm{Ph}}\right]-\Delta \mathrm{FID},
$$

and the expression of the expected response to one cycle of selection $\left(\mathrm{Rs}=\mathrm{u}_{1}-\mathrm{u}_{0}\right)$ taking into account the effective population size is:

$$
\mathrm{Rs}=\left[\mathrm{ic}\left(\sigma_{\mathrm{A}}^{2}+\Delta \mathrm{FD}_{1}\right) / \sigma_{\mathrm{Ph}}\right]-\Delta \mathrm{FID},
$$

and the accumulated response after $t$ cycles of selection is:

$$
\mathrm{Rs}=\left[\mathrm{ic}\left(\mathrm{t} \sigma_{\mathrm{A}}^{2}+\mathrm{F}_{\mathrm{t}} \mathrm{D}_{1}\right) / \sigma_{\mathrm{Ph}}\right]-\mathrm{F}_{\mathrm{t}} \mathrm{ID}
$$

These results were derived for one locus-two alleles model, but the extension for all loci is straightforward by letting $\sigma_{A}^{2}, D_{1}$ and ID be the sum for all loci, as follows:

$$
\sigma_{\mathrm{A}}^{2}=\sum_{\mathrm{k}} \sigma_{\mathrm{A}^{\mathrm{k}}}, \mathrm{D}_{1}=\sum_{\mathrm{k}} \mathrm{D}_{1}^{\mathrm{k}} \text {, and ID }=\sum_{\mathrm{k}} \mathrm{ID}^{\mathrm{k}} \text {. }
$$

The response to selection (Rs) has usually been estimated by using the following expression (Falconer and Mackay, 1996):

$$
\mathrm{Rs}=\mathrm{ic} \sigma^{2}{ }_{\mathrm{A}} / \sigma_{\mathrm{Ph}} .
$$

Notice that Equation 2 was derived on the assumption of infinite effective population size, whereas Equation 1 took into account the effective population size as finite. Thus, the expression derived in this study is less biased than Equation 2 because of the small number of progenies that has usually been recombined in recurrent selection programs (Smith, 1983). Comparing Equation 1 with
2 , we note that the difference is a function of the last two terms, i.e., the $\mathrm{D}_{1}$ and ID terms, related to genetic drift caused by small population size.

For most of the traits the term -Ft ID will reduce Rs, because it represents the decrease in the heterozygosity of the selected population. However, $\mathrm{D}_{1}$, as a covariance, may be either negative or positive (Cockerham, 1984), and then could reduce or increase Rs. The effects of genetic drift increase as selection cycles proceed. Then, $\mathrm{N}_{\mathrm{e}}$ should be maintained at a level such that this effect could be reduced, and, therefore, the response to selection could be maintained as high as possible.

It is important to note that genetic drift may also lead to the fixation of undesirable alleles. Even without dominance $(d=0)$, i.e., no inbreeding depression $(I D=0)$ and $D_{1}=0$, genetic drift may reduce the response to selection (Robertson, 1960).

It should be emphasized that genetic drift is affected by selection, because $\left(\delta \mathrm{p}^{\prime}\right)^{2}=(\delta \mathrm{p})^{2}\left[1+\mathrm{ic}\left(\mathrm{q}_{0}-\mathrm{p}_{0}\right) \alpha / \sigma_{\mathrm{Ph}}\right]$ for the selected sample, which results from the genetic drift of a random sample $(\delta p)^{2}$ plus the effects of selection on it. The second term is a function of the selection intensity (i), the selection procedure used (c), and the allele frequencies $\left(\mathrm{p}_{0}\right.$ and $\left.\mathrm{q}_{0}\right)$. Note that this term may be either positive or negative, because it depends on the differences between the allele frequencies of the same locus. Then, if this term is positive, $\left(\delta p^{\prime}\right)^{2}>(\delta p)^{2}$, and vice-versa.

The effective population size $(\mathrm{Ne})$ is also affected by a long-term selection, because as selection proceeds the individuals of the population under selection become genetically related, and, consequently, the inbreeding coefficient $\left(\mathrm{F}_{\mathrm{t}}\right)$ and the rate of inbreeding $(\Delta \mathrm{F})$ increases (Wray and Thompson, 1990; Wray et al., 1994). Therefore, for a long-term selection, the increase in $F_{t}$ and in $\Delta F$ should be added to the formula derived in this paper; otherwise the response to selection would be overestimated.

Wei et al. (1996) derived a formula to predict response to selection in finite populations by jointly considering the effects of genetic drift, linkage disequilibrium, inbreeding depression, and mutational variance. However, they did not consider the effects of selection on genetic drift and, consequently, the component $\mathrm{D}_{1}$. Nonetheless, their results showed that mutational variance and effective population size could affect considerably the response to a long-term selection.

\section{Numerical evaluation}

Values of expected responses (Rs) for five cycles of selection were computed from parameter estimates of ESALQ-PB1 maize population for yield and plant height. Although theoretical results have shown that genetic variances change with selection and small population sizes (Nei, 1963; Cockerham, 1984), and that inbreeding depression is also expected to change with selection (Souza Jr., 1985), we considered $\sigma_{\mathrm{A}}^{2}, \mathrm{D}_{1}$, ID and $\sigma_{\mathrm{Ph}}$ as constant for all 
cycles. We assumed that these restrictions are stringent because experimental results have shown small changes in these parameters following selection (Stucker and Hallauer, 1992; San Vicente and Hallauer, 1993; Schnicker and Lamkey, 1993; Benson and Hallauer, 1994).

Estimates of response to one cycle of selection (Rs\%) for yield and plant height were 3.9 and $6.2 \%$, respectively, for finite size $\left(\mathrm{N}_{\mathrm{e}}=10\right)$, and 8.1 and $9.0 \%$, respectively, for infinite $\mathrm{N}_{\mathrm{e}}$. Thus, the decreases in response when finite population size was taken into account were about 52 and $31 \%$ for yield and plant height, respectively. The greater decrease in yield occurred because of the higher level of dominance for this trait, which leads to a greater inbreeding depression. Note that these results refer to a half-sib selection scheme, where $10 \mathrm{~S}_{1}$ progenies were used for recombination. The expected accumulated decrease in yield due to $i \mathrm{ic}_{\mathrm{t}} \mathrm{D}_{1} / \sigma_{\mathrm{Ph}}$ and $\mathrm{F}_{\mathrm{t}} \mathrm{ID}$ following five cycles of selection for several $\mathrm{N}_{\mathrm{e}}$ 's (Table III) showed that as $\mathrm{N}_{\mathrm{e}}$ decreases and cycles of selection proceed, the effects of ID and $D_{1}$, related to the genetic drift, increase as expected. For example, at the $5^{\text {th }}$ selection cycle, the accumulated decrease from $\mathrm{N}_{\mathrm{e}}=30(13.71 \mathrm{~g} / \mathrm{plant})$ to $\mathrm{N}_{\mathrm{e}}=10(38.47 \mathrm{~g} / \mathrm{plant})$ increased about $181 \%$. Also, for $\mathrm{N}_{\mathrm{e}}=10$ the accumulated decrease from the $1^{\text {st }}(8.51 \mathrm{~g} / \mathrm{plant})$ to the $5^{\text {th }}(38.47 \mathrm{~g} /$ plant) cycle of selection increased about $352 \%$. Note that the contributions of $\mathrm{D}_{1}$ and ID to the decrease were different, with the $\mathrm{F}_{\mathrm{t}} \mathrm{ID}$ component being about 40 times greater than the $\mathrm{icF}_{\mathrm{t}} \mathrm{D}_{1} / \sigma_{\mathrm{Ph}}$ component.

Expected responses to selection for yield, considering the intensity of selection (10\%) to be constant, and varying the number of progenies evaluated, i.e., varying the effective population size (Figure 1), showed an increase in the response to selection as $\mathrm{N}_{\mathrm{e}}$ increased. Nevertheless, this increment was not linear, increasing sharply up to $\mathrm{N}_{\mathrm{e}}=$ 20 and decreasing thereafter. For instance, the response to selection for $\mathrm{N}_{\mathrm{e}}=20$ was about $42 \%$ greater than that for $\mathrm{N}_{\mathrm{e}}=10$, whereas the response to selection for $\mathrm{Ne}=30$ was only $11 \%$ greater than that for $\mathrm{N}_{e}=20$. Thus, for yield in maize it seems worthwhile keeping the effective size number at least at 20. Considering the method and the intensity of selection used in this example, where $S_{1}$ progenies are used for recombination, the number of progenies to be evaluated should be around 200 to lower the inbreeding depression caused by the small population size.

Another situation, where the number of progenies to be evaluated is constant (100) but not the intensity of selection, i.e., varying $\mathrm{N}_{\mathrm{e}}$ 's from 10 to 30 , for yield was also considered (Figure 2). Results showed that the expected response to selection increased as the intensity of selection increased from 30 to $20 \%$, but decreased thereafter (from 20 to $10 \%$ ). This occurred because of the decrease in the effective population size that offsets the response to selection as shown in Table III. Despite the small differences in responses to selection, it would be important to maintain effective size as high as possible because genetic variance is expected to become smaller due to small population size.
General results for five cycles of selection for plant height, considering constant intensity of selection (10\%) but varying effective population size by increasing the number of progenies evaluated (Figure 3), showed the same pattern as for yield (Figure 1), but with smaller differences among varying $\mathrm{N}_{\mathrm{e}}$ 's. The level of dominance for plant height was lower than that for yield, and, consequently, its inbreeding depression was smaller than for yield (Hallauer et al., 1988). Thus, the differences among

Table III - Expected decreases in the response to five cycles of half-sib selection due to $i \mathrm{icF}_{\mathrm{t}} \mathrm{D}_{1} / \sigma_{\mathrm{Ph}}(\mathrm{A}), \mathrm{F}_{\mathrm{t}} \mathrm{ID}(\mathrm{B})$, and the sum $(\mathrm{A}+\mathrm{B})$ for three population sizes $\left(\mathrm{N}_{\mathrm{e}}\right)$, for maize yield (g/plant) at $10 \%$ selection intensity.

\begin{tabular}{|c|c|c|c|c|c|c|c|c|c|}
\hline \multirow[t]{3}{*}{ Cycles } & \multicolumn{3}{|c|}{$\mathrm{icF}_{\mathrm{t}} \mathrm{D}_{1} / \sigma_{\mathrm{Ph}}{ }^{\mathrm{a}}(\mathrm{A})$} & \multicolumn{3}{|c|}{$\mathrm{F}_{\mathrm{t}} \mathrm{ID}(\mathrm{B})$} & \multicolumn{3}{|c|}{$A+B$} \\
\hline & \multicolumn{3}{|c|}{$\mathrm{N}_{\mathrm{e}}$} & \multicolumn{3}{|c|}{$\mathrm{N}_{\mathrm{e}}$} & \multicolumn{3}{|c|}{$\mathrm{N}_{\mathrm{e}}$} \\
\hline & 10 & 20 & 30 & 10 & 20 & 30 & 10 & 20 & 30 \\
\hline 1 & 0.21 & 0.10 & 0.07 & 8.30 & 4.15 & 2.77 & 8.51 & 4.25 & 2.84 \\
\hline 2 & 0.41 & 0.21 & 0.14 & 16.18 & 8.20 & 5.49 & 16.59 & 8.41 & 5.63 \\
\hline 3 & 0.60 & 0.31 & 0.21 & 23.66 & 12.13 & 8.16 & 24.26 & 12.44 & 8.37 \\
\hline 4 & 0.77 & 0.40 & 0.27 & 30.78 & 15.90 & 10.79 & 31.55 & 16.38 & 11.06 \\
\hline 5 & 0.94 & 0.50 & 0.34 & 37.53 & 19.73 & 13.37 & 38.47 & 20.23 & 13.71 \\
\hline
\end{tabular}

$\mathrm{a}_{\mathrm{i}}=1.755 ; \mathrm{c}=0.50$.

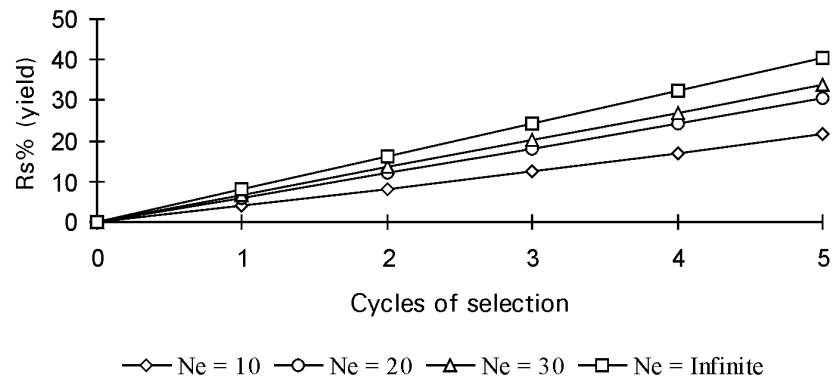

Figure 1 - Expected responses to five cycles of half-sib selection (Rs\%) for maize yield, considering $10 \%$ selection intensity and several population sizes.

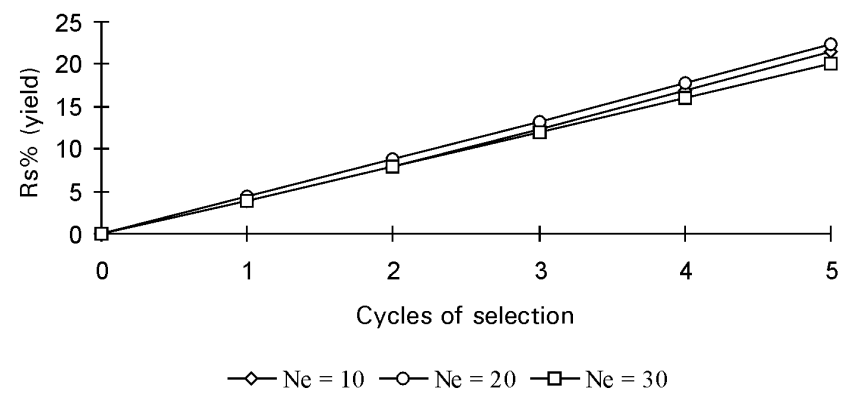

Figure 2 - Expected responses to five cycles of half-sib selection (Rs\%) for maize yield, considering several population sizes and selection intensities, for a constant number of progenies evaluated (100). 


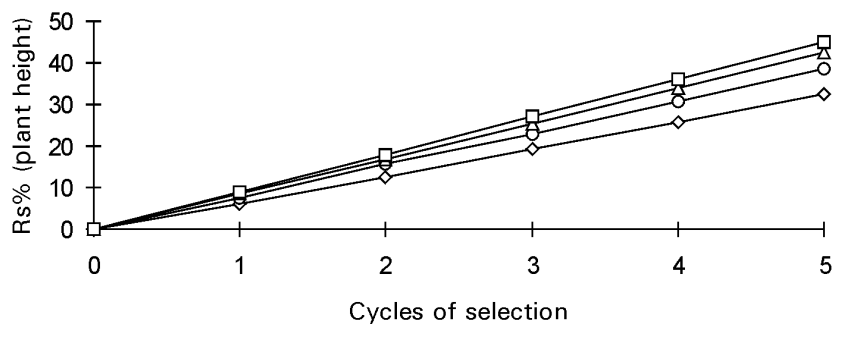

$\leadsto \sim \mathrm{Ne}=10 \multimap-\mathrm{Ne}=20 \multimap-\mathrm{Ne}=30 \multimap \square \mathrm{Ne}=$ Infinite

Figure 3 - Expected responses to five cycles of half-sib selection (Rs\%) for plant height in maize, considering $10 \%$ selection intensity and several population sizes.

the responses to selection by varying $\mathrm{N}_{\mathrm{e}}$ 's for plant height were smaller than for yield because of the lower level of dominance of this trait.

Discrepancies between the expected and observed responses to selection can also be explained by sampling errors, precision of estimates, and genotype-environment interaction. Sampling errors could occur during the recombination of selected progenies; estimates of genetic and phenotypic variances generally have low precision, and genotype-environment interaction may reduce the response to selection, mainly in atypical years. Also, errors can occur in the expected response by using the standardized selection differential if the progeny means do not fit a normal distribution (Arriel et al., 1993). Recently, the effect of the gametic-phase disequilibrium was reported as another important source of discrepancies (Mackay and Gibson, 1993). Simulation studies by these authors showed reductions attributed to linkage disequilibrium between 16 and $32 \%$, when comparing observed and expected responses to selection.

It was shown in this study that effective population size $\left(\mathrm{N}_{\mathrm{e}}\right)$ is an important source of discrepancy between the expected and observed responses to selection, mainly when effective size is very small and the level of dominance of the trait is high. We have considered, for the sake of simplicity, only half-sib selection, but deriving expressions for other selection schemes are straightforward by letting parental control (c), effective population size $\left(\mathrm{N}_{\mathrm{e}}\right)$, and the phenotypic standard deviation $\left(\sigma_{\mathrm{Ph}}\right)$ be those related to the selection scheme considered.

\section{ACKNOWLEDGMENTS}

\section{Publication supported by FAPESP.}

\section{RESUMO}

Foi derivada uma expressão para predizer a resposta à seleção recorrente para tamanhos efetivos populacionais $(\mathrm{Ne})$ pequenos. Usualmente, as respostas à seleção têm sido estimadas utilizando-se da expressão $\mathrm{R}_{\mathrm{s}}=\mathrm{ic} \sigma_{\mathrm{A}}^{2} / \sigma_{\mathrm{Ph}}$, onde i, c, $\sigma_{\mathrm{A}}^{2}$ e $\sigma_{\mathrm{Ph}}$ referem-se ao diferencial de seleção estandardizado, controle pa- rental, variância genética aditiva e desvio-padrão fenotípico, respectivamente. Entretanto, essa expressão foi derivada assumindo que o tamanho efetivo populacional é infinito. Considerando que a população sob seleção é finita, derivou-se uma nova expressão considerando o tamanho efetivo populacional finito: $R_{\mathrm{S}}=\left[\mathrm{ic}\left(\sigma_{\mathrm{A}}^{2}+\right.\right.$ $\left.\left.\left.\Delta \mathrm{FD}_{1}\right) / \sigma_{\mathrm{Ph}}\right)-\Delta \mathrm{FID}\right]$, onde $\Delta \mathrm{F}, \mathrm{ID}, \mathrm{e} \mathrm{D}_{1}$ referem-se às alterações no coeficiente de endogamia, à depressão por endogamia, e à covariância dos efeitos aditivos e de dominância dos homozigotos, respectivamente. Portanto, as respostas esperadas à seleção baseadas nesta expressão serão inferiores àquelas obtidas na expressão padrão, principalmente para caracteres com elevados níveis de dominância como produção de grãos. Foram estimadas as respostas à seleção recorrente com progênies de meios-irmãos para uma população de milho utilizando-se as duas expressões, considerando-se a avaliação de 100 progênies e recombinação de 10 progênies $S_{1}$ 's, o que corresponde a um tamanho efetivo de $\mathrm{Ne}$ $=10$ para cada ciclo. A resposta à seleção acumulada estimada com a nova expressão foi cerca de 47 e $28 \%$ inferior para produção de grãos e altura da planta, respectivamente, que aquela obtida com a expressão usual que não considera o tamanho efetivo populacional. Portanto, a expressão padrão que tem sido utilizada superestima as respostas à seleção recorrente, como tem sido reportado na literatura, por não considerar o tamanho efetivo populacional normalmente baixo nestes tipos de programas.

\section{REFERENCES}

Arriel, E.F., Ramalho, M.A.P. and Pacheco, C.A.P. (1993). Expected and realized gains in the CMS-39 maize population after three cycles of half-sib family selection. Rev. Bras. Genet. 16: 1013-1018.

Benson, D.L. and Hallauer, A.R. (1994). Inbreeding depression rates in maize populations before and after recurrent selection. J. Hered. 85 : $122-128$.

Burton, J.W., Penny, L.H., Hallauer, A.R. and Eberhart, S.A. (1971). Evaluation of synthetic population developed from a maize variety (BSR) by two methods of recurrent selection. Crop Sci. 11: 361-365.

Cockerham, C.C. (1984). Covariances of relatives for quantitative characteres with drift. In: Human Population Genetics: The Pittsburgh Symposium (Chakravati, A., ed.). Van Nostrand Reinhold Co., New York, pp. 195-208.

Cockerham, C.C. and Matzinger, D.F. (1985). Selection response based on selfed progenies. Crop Sci. 25: 483-488.

Crossa, J. and Gardner, C.O. (1989). Predicted and realized grain yield responses to full-sib family selection in Cimmyt maize populations. Theor. Appl. Genet. 77: 33-38.

Empig, L.T., Gardner, C.O. and Compton, W.A. (1972). Theoretical Gains for Different Population Improvement Procedures. (M.P. 26). University of Nebraska, Nebraska.

Eyherabide, G.H. and Hallauer, A.R. (1991). Reciprocal full-sib selection in maize. II: Contributions of additive, dominance and genetic drift effects. Crop Sci. 31: 1442-1448.

Falconer, D.S. and Mackay, T.F. (1996). Introduction to Quantitative Genetics. 4th edn. Longman Scientific \& Technical, New York.

Hallauer, A.R., Russell, W.A. and Lamkey, K.R. (1988). Corn breeding. In: Corn and Corn Improvement (Dudley, J.W. and Sprague, G.F., eds.). 3rd edn. ASA, CSSA, ASSSA, Madison, pp. 463-564.

Helms, T.C., Hallauer, A.R. and Smith, O.S. (1989). Genetic drift and selection evaluated from recurrent selection programs in maize. Crop Sci. 29: 602-607.

Keeratinijakal, V. and Lamkey, K.R. (1993). Genetic effects associated with reciprocal recurrent selection in BSSS and BSCB1 maize populations. Crop Sci. 33: 78-82.

Kempthorne, O. (1957). An Introduction to Genetic Statistics. John Wiley \& Sons, Inc., New York.

Mackay, I.J. and Gibson, J.P. (1993). The effect of gametic-phase disequilibrium on the prediction of response to recurrent selection in plants. 
Theor. Appl. Genet. 87: 152-160.

Nei, M. (1963). Effect of selection on the components of genetic variance. In: Statistical Genetics and Plant Breeding (Hanson, W.D. and Robinson, H.F., eds.). Publication 982 NAS-NRC, Washington, pp. 501-515.

Penny, L.H. and Eberhart, S.A. (1971). Twenty years of reciprocal recurrent selection with two synthetic varieties of maize. Crop Sci. 11: 900-903.

Robertson, A. (1960). A theory of limits in artificial selection. Proc. R. Soc. Lond. Ser. B. 153: 234-249.

San Vicente, F.M. and Hallauer, A.R. (1993). Inbreeding depression rates of materials derived from two groups of maize inbred lines. Rev. Bras. Genet. 16: 989-1001.

Schnicker, B.J. and Lamkey, K.R. (1993). Interpopulation genetic variance after reciprocal recurrent selection in BSSS and BSCB1 maize populations. Crop Sci. 33: 90-95.

Smith, O.S. (1979a). A model for evaluating progress from recurrent selection. Crop Sci. 19: 223-226.

Smith, O.S. (1979b). Application of a modified diallel analysis to evaluate recurrent selection for grain yield in maize. Crop Sci. 19: 819-822.

Smith, O.S. (1983). Evaluation of recurrent selection in BSSS, BSCB1 and BS13 maize populations. Crop Sci. 23: 35-40.

Souza Jr., C.L. (1985). Procedures for estimating expected genetic progress in inbred lines via recurrent intrapopulation selection. Rev. Bras. Genet. VIII: 329-342.

Stucker, D.S. and Hallauer, A.R. (1992). Genetic variability as affected by selection in Iowa stiff stalk synthetic maize. J. Hered. 83: 410-418.

Wei, M., Caballero, A. and Hill, W.G. (1996). Selection response in finite populations. Genetics 144: 1961-1974.

Wray, N.R. and Thompson, R. (1990). Prediction of rates of inbreeding in selected populations. Genet. Res. 55: 41-54.

Wray, N.R., Wooliams, J.A. and Thompson, R. (1994). Prediction of rates of inbreeding in populations undergoing index selection. Theor. Appl. Genet. 87: 878-892.

(Received July 14, 2000) 